\title{
Size composition, monthly condition factor and morphometrics for fishery-dependent samples of Rioraja agassizi (Chondrichthyes: Rajidae), off Santos, Southeast Brazil
}

\author{
M. Cristina Oddone*, Alberto F. de Amorim**, Patrícia L. Mancini*** and Walter Norbis****
}

Specimens of Rioraja agassizi were collected monthly off Santos, Southeast Brazil, between latitudes $23^{\circ} 37^{\prime} \mathrm{S}$ and $27^{\circ} 40^{\prime} \mathrm{S}$, from March, 2005 to March, 2006. A total number of 278 males and 1023 females were captured. Observed depth range was 10$120 \mathrm{~m}$, being the species absent above $120 \mathrm{~m}$. Sex ratio significantly favored females. The entire length range of $R$. agassizi was observed. Females ranged in length from 16.0 to $59.4 \mathrm{~cm}$ and males from 13.0 to $47.2 \mathrm{~cm}$. Mean female length was significantly higher than that of males. For grouped length distributions, asymmetry patterns were observed in both sexes. Length-width functions were sexually dimorphic. Males with lengths $<24.5 \mathrm{~cm}$ were relatively wider than females. Length-total weight curves were significantly different than length-gutted weight ones, in both sexes. Females were heavier than males for a given TL class. The angular coefficient $b$ was significantly $<3$ (negative allometry) in the males, and also for the females with exception of spring when $b$ was $>3$ (positive allometry). The monthly variation of the condition factor showed significant differences in both sexes.

Espécimes de Rioraja agassizi foram mensalmente coletados em águas ao largo de Santos, sudeste do Brasil entre as latitudes $23^{\circ} 37^{\prime} \mathrm{S}$ e $27^{\circ} 40^{\prime} \mathrm{S}$, desde março de 2005 até março de 2006. Um total de 278 machos e 1023 fêmeas foi capturado. A amplitude de profundidade de ocorrência foi $10-120 \mathrm{~m}$, estando a espécie ausente em profundidades $>120 \mathrm{~m}$. A razão sexual favoreceu as fêmeas. A amplitude completa de comprimentos de $R$. agassizi esteve representada e oscilou nas fêmeas entre 16.0-59.4 cm comprimento e nos machos entre 13.0-47.2 cm. O tamanho médio das fêmeas foi significativamente maior do que dos machos. A distribuição de freqüência de comprimentos por amostras agrupadas foi assimétrica em ambos os sexos. As curvas da relação comprimento-largura foram sexualmente dimórficas. As fêmeas foram mais largas que os machos em todas as classes de comprimento maiores do que $25 \mathrm{~cm}$. As curvas comprimento-peso total foram significativamente diferentes das curvas comprimento-peso eviscerado em ambos os sexos. As fêmeas foram mais pesadas do que os machos para uma determinada classe de comprimento. O coeficiente angular b foi $<3$ nos machos (alometría negativa) e nas fêmeas, mas com exceção da primavera, onde a alometría foi positiva $(b>3)$. O fator de condição variou significativamente ao longo do ano em ambos os sexos.

Key words: Skates, Depth, Total length, Elasmobranch, Sex ratio.

\section{Introduction}

Skates (Rajidae) are widely distributed from Artic to Antarctic waters and from coastal to $\sim 3000 \mathrm{~m}$ deep, being rare in tropical waters especially in coral reefs (McEachran \& Notabartolo di Sciara, 1995) and absent from the Pacific Plate and Red Sea (Springer 1982 apud Last \& Yearsley, 2002). The genus Rioraja Whitley, 1939, has a single species, the 'rio skate' Rioraja agassizi (Müller \& Henle, 1841), commonly known in Brazil as 'raia-santa'. The absence of a caudal fin is a distinct character of this species (Figueiredo, 1977).

From a biogeographic perspective, $R$. agassizi belongs to the pattern of species endemic to the austral region of South America, being, along with the genus Atlantoraja, limited to

\footnotetext{
*Universidade Estadual Paulista, Departamento de Ecologia, Campus Rio Claro Av. 24-A 1515, Caixa Postal 199, 13506-900 Rio Claro, SP, Brazil.mcoddone@rc.unesp.br

**Instituto de Pesca, Av. Bartolomeu de Gusmão, 192, Ponta da Praia, 11030-906 Santos, SP, Brazil.

****Projeto Albatroz. Av. Rei Alberto I, N. 450, sala 5, Ponta da Praia, 11030-906 Santos, SP, Brazil

****Dirección Nacional de Recursos Acuáticos, Departamento de Biología Pesquera, Constituyente 1497, PO Box 1612, Montevideo, 11200, Uruguay.
} 
the south-western region of the Atlantic Ocean (McEachran \& Miyake, 1990; McEachran \& Aschliman, 2004; Compagno, 2005). The species ranges from Espírito Santo State (Brazil) to Argentina, inhabiting coastal waters from the shore down to $130 \mathrm{~m}$ (Figueiredo, 1977).

Despite the uniform-brown coloration, there are two darker oval ocelli with a light or dark center, in the inner area of the pectoral fins, being highly variable in shape and with a lighter ring around them. In some individuals, this circle is surrounded by a single row of minute white points. Throughout the dorsal face of the skate, little, circular; white and symmetrically placed spots can occur, even in the pelvic fins area, in adult as well as young (Figueiredo, 1977; Barbosa \& Gomes, 1998; Oddone, pers. obs.). The white ventral surface with white and light pink tones allows it to be distinguished from young Atlantoraja platana with which at first sight it could be mistaken. Light ventral colouration in $R$. agassizi is typical of species that inhabit shallow waters (McEachran \& Notabartolo di Sciara, 1995).

Male $R$. agassizi attains sexual maturity at $32 \mathrm{~cm}$ and females at $40 \mathrm{~cm}$ of total length (Oddone et al., 2007). Rioraja agassizi is a benthic feeder, preying mainly on Crustacea, especially Amphipoda, Caridea and Brachyura and Teleostei (Muto et al., 2001).

Skates, as other elasmobranches, are long-lived, attain sexual maturity at large size and have low fecundity and long development period. These features make them susceptible to overexploitation (Walker, 1999). Casarini (2006) estimated the longevity of $R$. agassizi to be as 20 and 23 years respectively for males and females. It is important for management purposes to know where the center of the stock is and if it is subject to seasonal variation (Walker, 1999). In Southeast Brazil, only the large individuals of $R$. agassizi are landed and exported (Casarini, 2006).

The aim of this work was to describe the latitudinal and bathymetric distribution of $R$. agassizi in the fishing area of Santos and Guarujá's fishing fleet (southeast Brazil); to analyze the frequency composition of total length for both sexes and the relationships between total length and total width, and total and gutted weight; to establish the type of growth in weight with total length (allometry/isometry); and finally to determine the condition factor throughout a year.

\section{Materials and Methods}

Samples of Rioraja agassizi were obtained through a partnership system with fishermen as it is mostly a non commercialized species (Casarini, 1999). A total of eight fishing vessels (trawler and paired trawler), took part in the survey, bringing regularly (once or twice a month) samples of this species. Vessels' length over all ranged from 19.5 to $22.5 \mathrm{~m}$ and beam from 5.3 to $13 \mathrm{~m} \mathrm{~m}$. The stretched mesh of the trawlnet varied from 45 to $90 \mathrm{~mm}$ and the groundrope ranged from 22 to $70 \mathrm{~m}$.

Whenever possible, skippers identified the sample bag with a number corresponding with a trawling position, along with it characteristics, recorded on a board map. Data collected for each trawl were: date, depth, latitude/longitude, number of hauls and number of hauls with occurrence of the species. As the presence/absence of the species per haul was not regularly recorded, and since when recorded the information was imprecise, it was assumed that such data is unknown.

Study area was located between latitudes $23^{\circ} 37^{\prime} \mathrm{S}$ and $27^{\circ} 40^{\prime}$ S, including States of Rio de Janeiro, São Paulo, Paraná and Santa Catarina, at depths between 10 to 146 m (Fig. 1). Samples were collected monthly from March, 2005 to March, 2006 (Table 1).

Biometric measurements were: total length (TL, cm), total width (DW, cm), total weight $\left(\mathrm{T}_{\mathrm{W}}, \mathrm{g}\right)$ and gutted weight (body weight without digestive tract, liver and gonads and oviduct for the females, Gw, g). Linear measurements were made with $0.1 \mathrm{~cm}$ precision. Electronic scales used had 1 and $5 \mathrm{~g}$ precision respectively.

The Condition Factor (CF) was calculated monthly according to King (1995): $\mathrm{CF}_{\mathrm{T}}=\mathrm{Tw} / \mathrm{TL}^{\mathrm{b}}$ and $\mathrm{CF}_{\mathrm{G}}=\mathrm{Gw} / \mathrm{TL}^{\mathrm{b}}$, where the sub-indexes $\mathrm{T}$ and $\mathrm{G}$ are the total and gutted weight, respectively, $\mathrm{b}$ is the angular coefficient of the potential curve adjusted to the relationship TL-Tw and TL-Gw.

The use of parametric/non-parametric tests was chosen by testing the normality and homogeneity of the variables' variance by Lilliefors' and Levene's tests respectively. To compare TL-Tw/Gw curves, data were log-transformed to become linear and the F-test was used (Souza, 1998). Sex ratios were tested using $\chi^{2}$. To assess the nature of the growth in weight with TL (isometry, allometry, etc.), the value of the angular coefficient $b$ was compared with the theoretical value of 3. For this purpose, monthly samples of males and females were grouped by season, that is, summer (January, February, March), autumn (April, May, June), winter (July, August, September) and spring (October, November, December). Comparisons among CF obtained for all individuals by month, were performed using Kruskal-Wallis' H-test and post-hoc Mann-

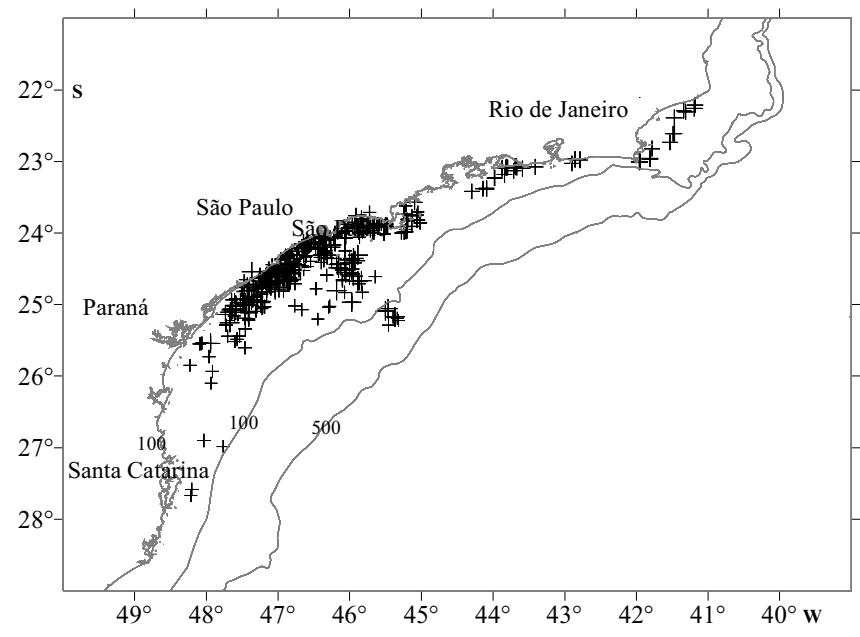

Fig. 1. Map of the study area, southeast Brazil, south-western Atlantic Ocean. Symbols represent all the fishing hauls from where samples of Rioraja agassizi were collected. 
Whitney's U-test Bonferroni corrected (Sokal \& Rohlf, 1995), using the freeware packet PAST (Hammer et al., 2001). In all cases the significance level considered was 0.05 .

\section{Results}

A total number of 278 males and 1023 females of $R$. agassizi were collected in 25 fishing trips, carried out from March, 2005 to March, 2006 by 8 fishing vessels of Guaruja's fishing fleet. The species was captured monthly, during the entire period. Ob- served depth range was 10-120, being absent below $120 \mathrm{~m}$ (Table 1). Descriptive statistics for the monthly $R$. agassizi samples by sex are presented in Table 2 . In the area covered by the vessels, the species occurred throughout the year (Fig. 2).

Sex ratio (M:F) for the samples was 1:3.7, significantly different from the 1:1 ratio throughout the year, varying from 1:1.19 (July) and 1:5.9 (March 2005), in all cases significantly favoring the females ( $>0.000$, Table 2$)$.

Considering grouped samples, the entire TL range of $R$. agassizi was observed. Females ranged in TL from 16.0 to

Table 1. Fishing trips carried out by eight fishery vessels of Guaruja's (Southeast Brazil) fishing fleet conducted from March of 2005 to March of 2006 from which samples of Rioraja agassizi were obtained; name of the fishing vessels, date (days, month, year), number of hauls and number of hauls with presence of the species $(*)$, depth of the hauls and depth with presence of the species $\left(^{*}\right)$. Days marked with $\left(^{*}\right)$ represent single days when Rioraja agassizi were collected, when this information was available. *dates where samples of Rioraja agassizi were collected; total trip days are unknown.

\begin{tabular}{|c|c|c|c|c|c|c|c|}
\hline Vessel's name & Year & Date & Month & $\mathrm{N}^{\circ}$ hauls & $\mathrm{N}^{\circ}$ hauls* & Depth & Depth* \\
\hline Antares e Polares & 2005 & $13-22$ & March & 16 & 15 & - & $10-23$ \\
\hline Antares e Polares & 2005 & $30 / 3-12 / 4$ & March-April & 16 & 4 & - & $19-26$ \\
\hline Cigano do Mar III e IV & 2005 & $20-26$ & April & 25 & 0 & $18-25$ & $23-24$ \\
\hline Jangadeiro & 2005 & 2 e $11 *$ & April & - & - & - & $50-52$ \\
\hline Antares e Polares & 2005 & $17 / 4-10 / 5$ & April-May & 19 & 3 & - & $10-32$ \\
\hline Dourado e Araguaia & 2005 & 5 & May & 6 & 5 & - & $22-33$ \\
\hline Cigano do Mar III e IV & 2005 & $4-18$ & May & 45 & 29 & $19-60$ & $23-29$ \\
\hline São Paulo II & 2005 & $10-27$ & May & - & & - & $53-120$ \\
\hline Antares e Polares & 2005 & $27 / 5-9 / 6$ & May-June & 13 & 2 & $14-24$ & 22 \\
\hline Cigano do Mar III e IV & 2005 & $22 / 5-2 / 6$ & May-June & 50 & 38 & $16-28$ & $16-20$ \\
\hline Cigano do Mar III e IV & 2005 & $28 / 6-13 / 7$ & June-July & 41 & - & $20-30$ & $20-30$ \\
\hline São Paulo IV & 2005 & $23 / 6-3 / 7$ & June-July & 10 & 2 & $48-100$ & $84-100$ \\
\hline Cigano do Mar III e IV & 2005 & $17-31$ & July & 42 & 3 & & $22-14$ \\
\hline Antares e Polares & 2005 & $29 / 7-8 / 8$ & July-August & 25 & 9 & $20-44$ & $23-34$ \\
\hline Cigano do Mar III e IV & 2005 & $4-14$ & August & 28 & 3 & $18-53$ & $35-50$ \\
\hline Antares e Polares & 2005 & $22 / 9-7 / 10$ & September & 23 & - & $22-34$ & $22-33$ \\
\hline Antares e Polares & 2005 & $24-29 *$ & November & 7 & 2 & $12-30$ & $22-28$ \\
\hline Antares e Polares & 2005 & $4-19$ & November & 17 & 4 & $17-30$ & $22-28$ \\
\hline Dourado e Araguaia & 2005 & 19 & November & - & - & - & $22-24$ \\
\hline Antares e Polares & 2005 & $28 / 11-6 / 12$ & November-December & 20 & 4 & $10-30$ & $18-25$ \\
\hline Franzese & 2005 & $17 / 10-27 / 11$ & October-November & - & 7 & - & $46-68$ \\
\hline São Paulo IV e XI & 2006 & $28 / 1-8 / 2$ & January-February & - & - & $11-18$ & 12 \\
\hline Franzese & 2006 & $10 / 2-4 / 3$ & February & - & 6 & - & $16-47$ \\
\hline São Paulo II & 2006 & $4 / 1-10 / 2$ & January-February & 22 & 2 & $52-146$ & $52-87$ \\
\hline São Paulo IV e XI & 2006 & $7-9 *$ & March & - & - & - & $23-38$ \\
\hline
\end{tabular}

Table 2. Number of males and females of Rioraja agassizi captured by month; total length range (cm), mean total length (mean), standard deviation (SD) and sex ratio males:females (M:F), along with $\chi^{2}$ test's value, degrees of freedom (d. f.) and probability (p).

\begin{tabular}{|c|c|c|c|c|c|c|c|c|c|c|c|c|}
\hline \multirow[t]{2}{*}{ Month } & \multicolumn{4}{|c|}{ Males } & \multicolumn{4}{|c|}{ Females } & \multicolumn{4}{|c|}{ Sexual ratio } \\
\hline & $\mathrm{N}^{\circ}$ & range & mean & SD & $\mathrm{N}^{\circ}$ & range & mean & SD & M:F & $\chi^{2}$ & d. f. & $P$ \\
\hline March & 18 & $27.3-43.0$ & 36.7 & 4.2 & 106 & $32.4-54.2$ & 46.8 & 3.4 & $1: 5.9$ & 62.5 & 1 & 0.0000 \\
\hline April & 15 & $24.9-44.3$ & 37.7 & 6.3 & 232 & $16.0-59.2$ & 46.5 & 4.8 & $1: 15.9$ & 190.6 & 1 & 0.0000 \\
\hline May & 31 & $37.7-39.3$ & 41.2 & 2.6 & 111 & $34.9-59.4$ & 47.9 & 4.9 & $1: 3.6$ & 45.1 & 1 & 0.0000 \\
\hline June & 25 & $13.0-47.2$ & 37.0 & 5.6 & 110 & $33.8-55.0$ & 47.0 & 3.6 & $1: 4.4$ & 53.5 & 1 & 0.0000 \\
\hline July & 44 & $33.2-45.0$ & 38.5 & 2.6 & 82 & $32.3-56.2$ & 47.7 & 3.5 & $1: 1.9$ & 11.5 & 1 & 0.0007 \\
\hline August & 36 & $34.0-43.0$ & 40.2 & 2.1 & 82 & $41.2-54.7$ & 48.6 & 3.2 & $1: 2.3$ & 17.9 & 1 & 0.0000 \\
\hline September & 13 & $34.2-42.0$ & 38.4 & 2.1 & 31 & $30.2-52.5$ & 46.7 & 4.3 & $1: 2.4$ & 7.4 & 1 & 0.0065 \\
\hline October & 16 & $33.3-44.0$ & 38.0 & 2.6 & 31 & $41.1-53.0$ & 53.0 & 2.8 & $1: 1.9$ & 4.8 & 1 & 0.0284 \\
\hline November & 40 & $33.0-44.5$ & 38.3 & 2.5 & 89 & $33.0-53.5$ & 46.0 & 4.7 & $1: 2.2$ & 18.6 & 1 & 0.0000 \\
\hline December & 8 & $36.0-39.8$ & 38.0 & 1.1 & 37 & $43.7-52.5$ & 48.2 & 2.4 & $1: 4.6$ & 18.7 & 1 & 0.0000 \\
\hline January & 9 & $31.0-45.8$ & 39.7 & 4.5 & 25 & $33.8-51.2$ & 45.6 & 4.4 & $1: 2.8$ & 7.5 & 1 & 0.0062 \\
\hline February & 14 & $27.0-43.5$ & 37.6 & 4.1 & 57 & $34.0-50.4$ & 43.4 & 4.0 & $1: 4.1$ & 26.0 & 1 & 0.0000 \\
\hline March & 9 & $35.2-44.2$ & 39.4 & 2.5 & 30 & $37.8-53.5$ & 47.0 & 4.1 & $1: 3.3$ & 11.3 & 1 & 0.0008 \\
\hline
\end{tabular}



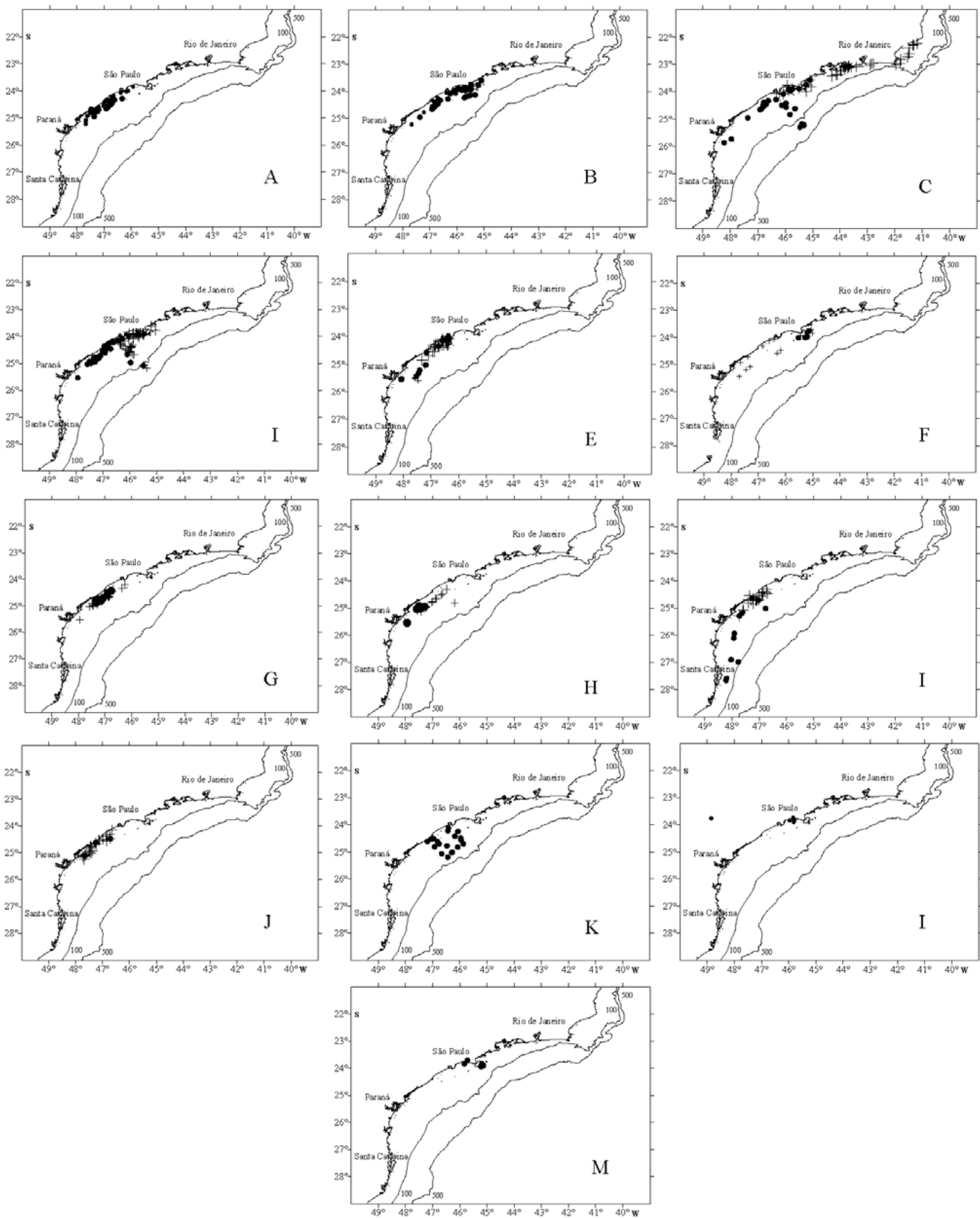

Fig. 2. Maps of Southeast Brazil, showing the fishing hauls by month, conducted by a total of eight fishing vessels. Symbols represent the fishing hauls from where samples of Rioraja agassizi were collected (dotted circles), or when this information was not available, the total hauls recorded by the skippers (crosses). 
$59.4 \mathrm{~cm}(\mathrm{n}=1019 ;$ mean $=46.9 ; \mathrm{SD}=4.4)$ and males from 13.0 to $47.2 \mathrm{~cm}(\mathrm{n}=278 ;$ mean=38.8; $\mathrm{SD}=3.4)$. Females were significantly larger than males ( $\mathrm{t}=-28.5 ; \mathrm{d}$. f. $=1295 ; \mathrm{p}<0)$, and such pattern was maintained monthly. The difference in mean TL for males and females in presented in Table 2. For grouped TL distributions, asymmetry patterns were observed in both sexes, with asymmetry values different from 0 (Table 2 ), varying from -1.8 to -1.3 for males and females, respectively (Fig. 3 ). The asymmetry pattern remained when monthly samples were considered, though varying between positive and negative values. In the males, positive asymmetry was observed in May, June, October, November, December and March of 2006, whereas only in December for females. Mean TL varied between 43.4 (February) and 53.0 (October) for the females and between 36.7 (March) and 41.2 (May) for the males (Table 2).

Total length/TW functions for $R$. agassizi were significantly different for both sexes $\left(\mathrm{F}_{(2,1291)}=75.2 ; \mathrm{p}<0.005\right)$ (Table 3). Males were wider than females for $\mathrm{TL}<24.5 \mathrm{~cm}$ $(\mathrm{TW}=17.4 \mathrm{~cm})$. From that size up, females become wider than males for all TL classes (Fig. 4). Total length-Tw potential curves were significantly different than TL-Gw curves (Table 3, Fig. 5) in females $\left(\mathrm{F}_{(2,1002)}=53.6 ; \mathrm{p}=0.000\right)$ and males $\left(\mathrm{F}_{(2,533)}=80.3 ; \mathrm{p}=0.000\right)$. Females were heavier than males for a given TL class, considering both $\mathrm{Tw}$ and $\mathrm{Gw}\left(\mathrm{F}_{(2,1279)}=75.2\right.$; $\mathrm{p}=0.000 ; \mathrm{F}_{(2,1132)}=580 ; \mathrm{p}=0.000$, respectively). In Table 4, mean values for Tw and Gw by month and sex along with the respective TL range are presented.

Males grew in weight in a negative allometric manner with $\mathrm{TL}(\mathrm{b}<3)$, when considering Tw as well as Gw, in the four seasons. The females, however, followed the same pattern of negative allometry, with exception of spring when their growth was positively allometric ( $b>3$ ) (Table 5 ).

For the males, July was not included in the calculation of

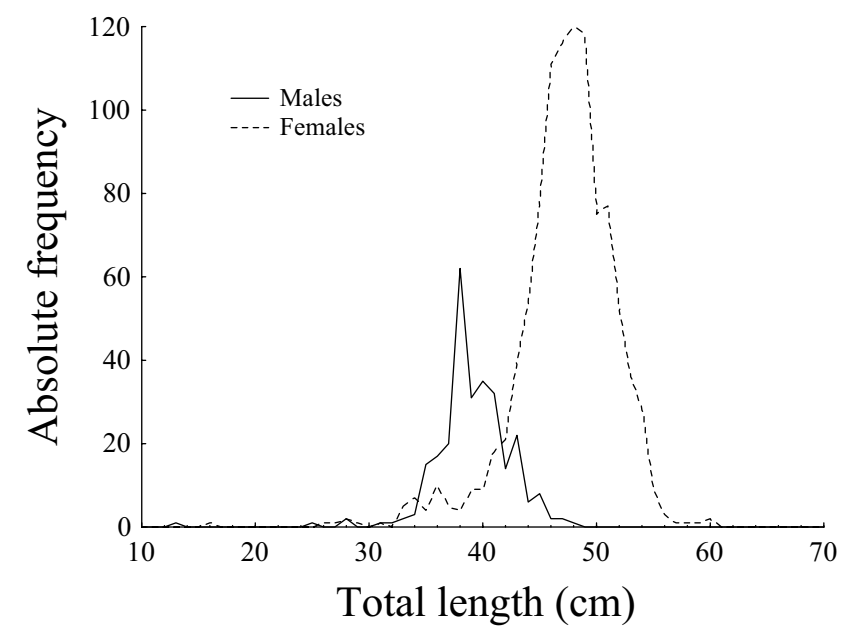

Fig. 3. Absolute frequency of total length $(\mathrm{cm})$ for males (full line) and females (dotted line) for grouped samples of Rioraja agassizi.
CF when considering Tw, and when considering Gw, June and July were not considered, because in those months the small sample led to outlier values for the angular coefficient b. This was due to the fact that only males with large TL values occurred, and because of the absence of juveniles in the samples, the potential curve was not properly adjusted. Kruskal-Wallis' test detected significant differences in the $\mathrm{CF}$ throughout the year, when considering $\mathrm{Tw}\left(\mathrm{H}_{(11, \mathrm{~N}=277)}\right.$ $=267.66, \mathrm{p}=0.0000))$ and $\mathrm{Gw}\left(\mathrm{H}_{(10, \mathrm{~N}=260)}=245.3, \mathrm{p}=0.0000\right)$. The overall median CF's value for Tw was 0.028. Post hoc pairwise comparisons were significant $(\mathrm{P}<0.05)$ between all the months with exception of: January-March/2006; December-March/2006; December-January; October-February; September-March/2006; September-January; September-December; June-August and April-February. For Gw, monthly differences between CF were mostly significant and were not significant for the pairs: January-March/2006; November/March; November-December; September-December; August-MNarch/2006; August-November; April-March/2006; April-February; April-January; April-December; April-October; April-September; March-March/2006; December-March/2006 and April-March/2006.

For the females, the CF significantly varied throughout the year, when considering both $\mathrm{Tw}$ and $\mathrm{Gw}\left(\mathrm{H}_{(12, \mathrm{~N}=1007)}=954.6\right.$, $\mathrm{p}=0.0000$ and $\mathrm{H}_{(12, \mathrm{~N}=939)}=840.0, \mathrm{p}=0.0000$, respectively). The overall median CF value for Tw was 0.0074 . Post hoc pairwise comparisons were significant $(\mathrm{P}<0.05)$ between all the months with exception of: February-March/2006; Ocotber-March/ 2006; October-February; May-December and MarchNovember. Overall CF with Gw median's value was 0.016 , with significant differences between all the month pairs $(\mathrm{P}<0.05)$, with exception of: February-March/2006; April-July; MarchMarch/2006 and March-February (Fig. 6, Table 4).

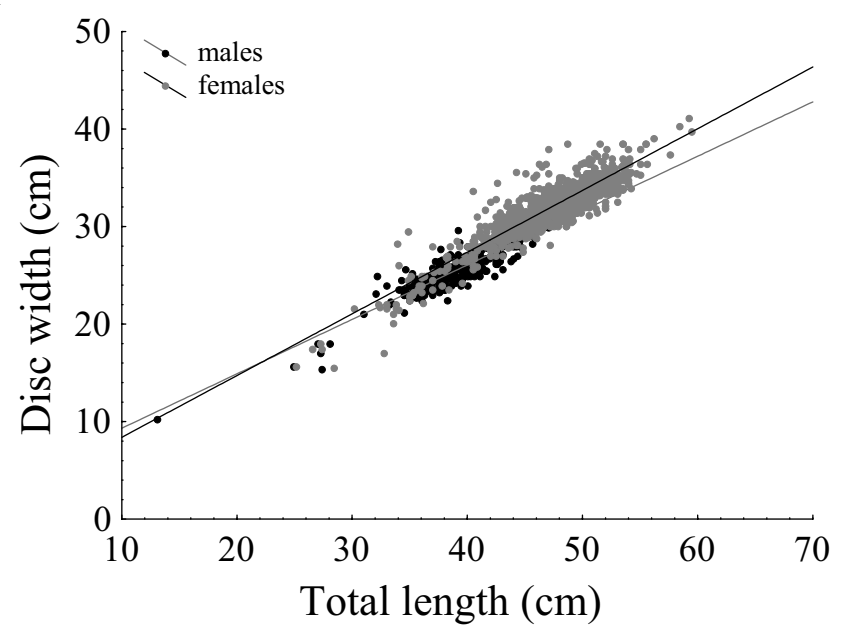

Fig. 4. Relationship of disc width $(\mathrm{cm})$ as a dependent variable of total length $(\mathrm{cm})$ for males (black symbols) and females (grey symbols) of Rioraja agassizi. 
Table 3. Relationships analyzed for Rioraja agassizi: $\mathrm{TL}=$ total length $(\mathrm{cm})$; $\mathrm{DW}=$ total width $(\mathrm{cm})$; $\mathrm{Tw}=$ total weight $(\mathrm{g})$; and $\mathrm{Gw}=$ gutted weight $(\mathrm{g})$ for males $(\mathrm{M})$ and females $(\mathrm{F})$, along with the respective regression equation and correlation coefficient $\left(\mathrm{R}^{2}\right)$, sample number (n); pair of relationships compared (comparisons) by F-test (F), along with degrees of freedom of the numerator (n. d. f.) and denominator (d. d. f), probability (p).

\begin{tabular}{|c|c|c|c|c|c|c|c|c|c|c|}
\hline Relationship & Sex & Equation & $\mathrm{R}^{2}$ & $\mathrm{n}$ & Comparisons & $\mathrm{F}$ & d. d. f. & n. d. f. & $\mathrm{p}$ & $\mathrm{R}^{2}$ \\
\hline 1 - TL-DW & $\mathrm{M}$ & $\mathrm{DW}=3.738+0.558 * \mathrm{TL}$ & 0.793 & 277 & $1-2$ & 75.2 & 2 & 1291 & 0.0000 & \\
\hline 2 - TL-DW & $\mathrm{F}$ & $\mathrm{DW}=2.061+0.633 * \mathrm{TL}$ & 0.799 & 1018 & - & - & - & - & - & \\
\hline 3 - TL-Tw & $\mathrm{M}$ & $\mathrm{Tw}=0.023 * \mathrm{TL}^{2.273}$ & 0.755 & 277 & $3-5$ & 80.3 & 2 & 533 & 0.0000 & \\
\hline 4 - TL-Tw & $\mathrm{F}$ & $\mathrm{Tw}=0.008 * \mathrm{TL}^{2.666}$ & 0.817 & 1008 & $4-6$ & 53.6 & 2 & 1002 & 0.0000 & 0.865 \\
\hline 5 - TL-Gw & $\mathrm{M}$ & $\mathrm{Gw}=0.095 * \mathrm{TL}^{2.163}$ & 0.562 & 260 & $3-4$ & 75.2 & 2 & 1279 & 0.0000 & \\
\hline 6 - TL-Gw & $\mathrm{F}$ & $\mathrm{Gw}=0.017 * \mathrm{TL}^{2.892}$ & 0.767 & 1002 & $5-6$ & 580 & 2 & 1132 & 0.0000 & 0.852 \\
\hline
\end{tabular}

Table 4. Monthly range, standard deviation (SD), and sample size (n) for total weight (Tw), gutted weight (Gw), angular coefficient (b), and $\mathrm{CF}$, calculated with both total and gutted weight (g) by total length range for males and females of Rioraja agassizi.

\begin{tabular}{|c|c|c|c|c|c|c|c|c|c|c|c|c|c|c|c|c|c|}
\hline \multirow[t]{2}{*}{ Month } & \multirow[t]{2}{*}{ TL } & \multicolumn{4}{|c|}{ Tw } & \multicolumn{3}{|c|}{ Gw } & $\mathrm{b}$ & \multicolumn{4}{|c|}{$\mathrm{CF} / \mathrm{Tw}$} & \multicolumn{4}{|c|}{$\mathrm{CF} / \mathrm{Gw}$} \\
\hline & & $\mathrm{n}$ & mean & range & SD & $\mathrm{n}$ mea & range & SD & Tw $\quad$ Gw & $\mathrm{n}$ & mean & range & $\mathrm{D}$ & $\mathrm{n}$ & mean & range & SD \\
\hline \multicolumn{18}{|l|}{ FEMALES } \\
\hline March 2005 & 5 & 101 & 5 & $15-945$ & 124.8 & 99517.2 & $225-823$ & & 2.7022 .6221 & 1 & 0.0022 & 0017 (1) & & & & & 0.00 \\
\hline ril & & & & 036 & & & & & & & & & & & & & \\
\hline & & & 619.8 & & 169.2 & & & & & 112 & 0173 & & & 89 & & & \\
\hline & & 105 & 563.1 & $193-923$ & 109.81 & 106504.08 & & 96.9 & 2.7202 .6721 & 105 & 0154 & 20 & 19 & 106 & & ( & 20 \\
\hline & & & & & & & & & & & & & & 81 & & & \\
\hline & & & & & & & & & & & & & & & & & \\
\hline & & 31 & 579.9 & & & & & & & 3 & & & & 31 & 23 & & \\
\hline & & 28 & & & & & & & & & & & & 28 & & & \\
\hline & & 89 & & & & & & & & & & & & & & & \\
\hline & 43 & 37 & 1.0 & & 108.7 & & & & & 3 & & & & & & & \\
\hline & & 24 & & & & & & & & 2 & & & & 5 & & & \\
\hline & & 57 & & & & & & & & 5 & & & & 57 & & & \\
\hline $10 \mathrm{Ic}$ & & 29 & 522.1 & & 135.3 & & & & & & & & & 29 & & & \\
\hline \multicolumn{18}{|l|}{$\overline{\mathrm{MALI}}$} \\
\hline & & & & & & & & & & & & & & & & & \\
\hline & & 15 & & & & 6 & & & & & & & & & & & \\
\hline & & 30 & & & & 302 & & & & 30 & & & & 30 & & & 79 \\
\hline & & & & & & & & & & & & & & 24 & & & \\
\hline & & & & & & & & & & & & & & & & & \\
\hline & & t & & & & & & & & 37 & & & & 37 & & 73 & \\
\hline & & & & & & & & & & 13 & & & & 13 & & & \\
\hline & & & & & & 15 & & & & 1 & & & & 15 & & & \\
\hline & $33-44.5$ & 40 & & & 52.562 & 34268.38 & & & 22.3 & 40 & & & & 34 & & 0.0 & 70.0072 \\
\hline & & 8 & & & & 8 & & & & 8 & & & & & & & \\
\hline & & ( & & & & 9 & & & & 9 & & & & & & & \\
\hline & $32-43.5$ & 14 & 267.14 & $4185-385$ & 59.702 & 14248.93 & & & 72.5302 .490 & 14 & & & & 14 & 0.02 & $0.0230-0.0$ & 30.002 \\
\hline 200 & $635.2-44.2$ & & & 1210 & 42.336 & 9 & 195 & 37.0 & 32.2302 .310 & 9 & 0.0770 & $0.0682-0.0854$ & 0.0054 & 9 & 0.05 & $0.0476-0$. & 40.003 \\
\hline
\end{tabular}

Table 5. Seasonal variation of the angular coefficient estimate (b) for males and females of Rioraja agassizi; standard error of the regression total length-total/gutted weight, $t_{1}=t$-test value of the regression and $p_{1}=$ probability of the regression regarding $\mathrm{b}$, correlation coefficient of the regression, $\mathrm{d}$. $\mathrm{f}$. $=$ degrees of freedom and probability $\left(\mathrm{p}_{1}\right), \mathrm{t}_{2}=\mathrm{t}$-test value of the comparison with the theoretical value 3 and probability $\left(\mathrm{p}_{2}\right)$ and the nature of growth according to $\mathrm{b}$.

\begin{tabular}{|c|c|c|c|c|c|c|c|c|c|c|c|}
\hline Sex & Season & Ratio & $\mathrm{b}$ & SE & $t_{1}$ & $\mathrm{p}_{1}$ & $\mathrm{r}$ & d. f. & $t_{2}$ & $\mathrm{p}_{2}$ & growth \\
\hline \multirow{8}{*}{ Males } & autumn & Tw & 2.869 & 0.0903 & 31.76 & 0.9679 & 0.9679 & 70 & -1.45 & $<0.05$ & allometric - \\
\hline & & Gw & 2.514 & 0.1819 & 13.82 & 0.8758 & 0.8758 & 70 & -2.67 & $<0.05$ & allometric - \\
\hline & summer & Tw & 2.671 & 0.2446 & 10.92 & 0.8443 & 0.8443 & 50 & -1.35 & $<0.05$ & allometric - \\
\hline & & Gw & 2.620 & 0.2322 & 11.29 & 0.8522 & 0.8522 & 50 & -1.64 & $<0.05$ & allometric - \\
\hline & spring & Tw & 2.399 & 0.2357 & 10.18 & 0.7909 & 0.7909 & 64 & -2.55 & $<0.05$ & allometric - \\
\hline & & Gw & 2.402 & 0.2322 & 10.35 & 0.8128 & 0.8128 & 64 & -2.57 & $<0.05$ & allometric - \\
\hline & winter & Tw & 1.065 & 0.2625 & 4.06 & 0.3914 & 0.3914 & 94 & -7.37 & $<0.05$ & allometric - \\
\hline & & Gw & 1.293 & 0.2594 & 4.98 & 0.4631 & 0.4631 & 94 & -6.58 & $<0.05$ & allometric - \\
\hline \multirow{8}{*}{ Females } & autumn & Tw & 2.756 & 0.1213 & 22.73018 & 0.0000 & 0.9065 & 424 & -2.01 & $<0.05$ & allometric - \\
\hline & & Gw & 2.437 & 0.1212 & 20.10460 & 0.0000 & 0.8849 & 386 & -4.65 & $<0.05$ & allometric - \\
\hline & summer & Tw & 2.984 & 0.1613 & 18.49753 & 0.0000 & 0.9133 & 71 & -0.10 & $<0.05$ & allometric - \\
\hline & & Gw & 2.888 & 0.1310 & 22.04357 & 0.0000 & 0.9266 & 71 & -0.85 & $<0.05$ & allometric - \\
\hline & spring & $\mathrm{Tw}$ & 3.279 & 0.1187 & 27.6267 & 0.0000 & 0.9131 & 154 & 2.35 & $<0.05$ & allometric + \\
\hline & & Gw & 3.609 & 0.1374 & 26.2636 & 0.0000 & 0.9509 & 75 & 4.43 & $<0.05$ & allometric + \\
\hline & winter & Tw & 2.540 & 0.0993 & 25.58354 & 0.0000 & 0.8793 & 194 & -4.63 & $<0.05$ & allometric - \\
\hline & & Gw & 2.502 & 0.0935 & 26.75574 & 0.0000 & 0.8880 & 194 & -5.32 & $<0.05$ & allometric - \\
\hline
\end{tabular}




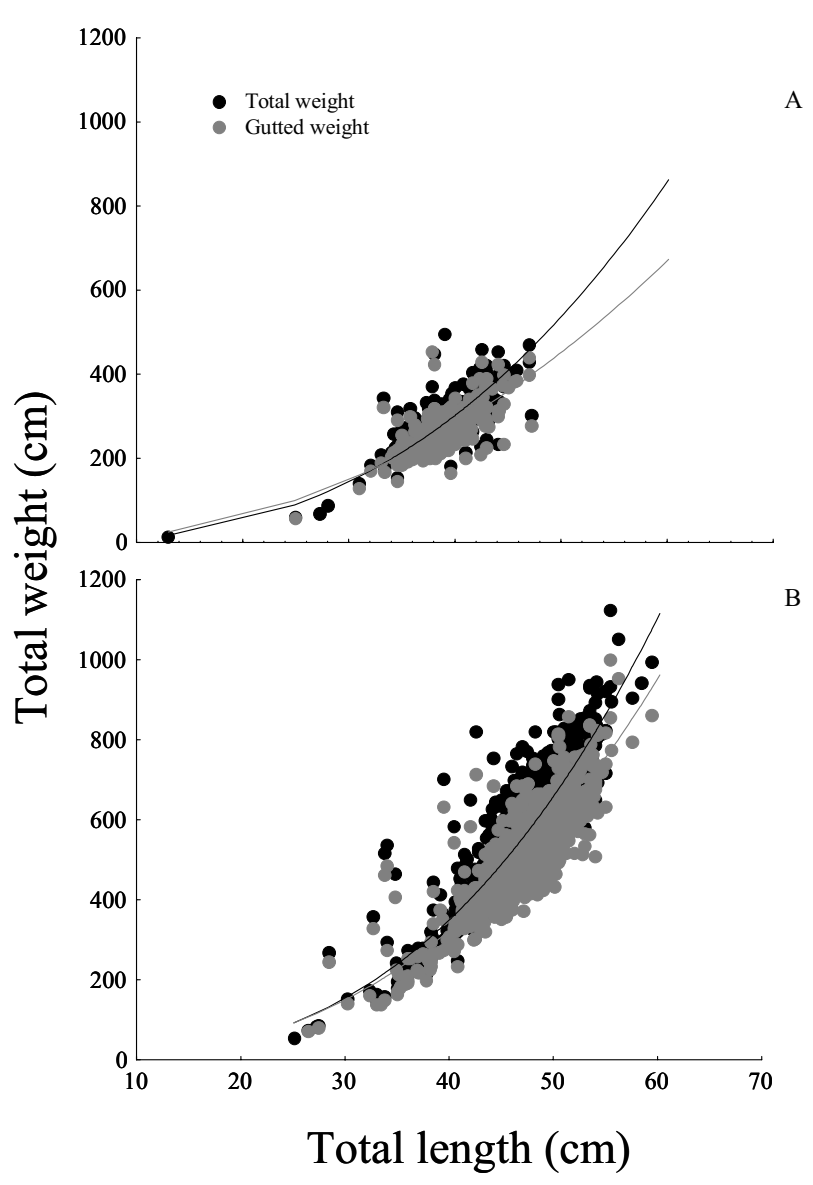

Fig. 5. Relationships between total (black symbols) and gutted weight (g) (grey symbols) for male (above) and females (below) of Rioraja agassizi.

\section{Discussion}

Information on habitat use in elasmobranchs is important not only with specific objectives such as determination of nursery area, but also for management purposes and species conservation. During the past decade, studies on habitat use have increased specially for commercially fished species and extracted by-catch, as is the case for the rajids (Simpfendorfer \& Heupel, 2004).

Fisheries have negatively affected rajid fishes, in part because of their mostly sedentary nature even to the point of extinction, rendering many species in a critical situation (Brander, 1981; Casey \& Myers, 1998; Dulvy \& Reynolds, 2002).

For fishery-dependent samples, it is not possible to obtain a reliable estimation of CPUE because we have only access to a 'fleeting image' of the real population (Walker, 1999), which is especially true for this work. This is due to the contradictory and low quality and reliability of the information provided by the skippers regarding the magnitude of total catch and discard. However, because of the monthly presence of $R$. agassizi in the samples, it is assumed that it is present in the area throughout the year without variation in its abundance.
Reinforcing this hypothesis, Ponz Louro (1995) observed that after Psammobatis glandissimilis, $R$. agassizi is the most abundant rajid in Ubatuba, São Paulo State, and Figueiredo (1977) had already considered the species as 'common' in the same area. For the Uruguayan inner shelf, $R$. agassizi together with Atlantoraja castelanui and A. cyclophora were distributed in $30-60 \%$ of the area with abundances between 1000 and $5000 \mathrm{~kg} /$ square nautical mile (Paesch, 2006).

Most skate species have a limited, well-defined distribution, and there are very few ranging species (Walker, 1999). It is known that $R$. agassizi ranges from Argentina to Rio de Janeiro (Brazil) (Figueiredo, 1977). Though precise limits of its distribution remain unknown to date, $R$. agassizi is probably distributed continuously along the cited range, because it is recorded in southeast and south Brazil, Uruguay and Argentina (Figueiredo, 1977; Menni \& Lopez, 1984; Vooren, 1998; Meneses \& Paesch, 2003).

With regard to depth of occurrence, Menni \& Lopez (1984) classified $R$. agassizi as belonging to the 'inner shelf mixed fauna' fish group (Menni \& Gosztonyi, 1982). McEachran \& Miyake (1990) stated that $R$. agassizi occurred at depths down to $\sim 50 \mathrm{~m}$. However, in this study, $R$. agassizi was recorded at maximum depths of $120 \mathrm{~m}$ and Menni \& Lopez (1984) stated its depth range was from 22 to $89 \mathrm{~m}$. For the south Brazilian area, Vooren (1998) confirmed its presence at depth of 20-50 $\mathrm{m}$, in agreement with Compagno (2005) who considers this species as demersal in the shelf of it distribution range. For Vooren op.cit., R. agassizi is a species of constant presence in south Brazil, which completes it cycle entirely in these waters without seasonal variations in its abundance, being one of the 27 elasmobranch species recorded in the South Brazilian shelf(Vooren \& Klippel., 2005). Menni et al. (1981) recorded the southernmost limit for this species in the Golfo de San Matías (Argentina, at 41 $30^{\circ}$ '), where it is fished at up to $181 \mathrm{~m}$ deep, while Figueiredo (1977) considered that the species occurred at a maximum depth of $130 \mathrm{~m}$ in southwest Brazil. In Ubatuba, São Paulo's State's littoral area, R. agassizi occurs only in the coastal area at down to $50 \mathrm{~m}$, with similar proportions of males and females during the whole year (Ponz Louro, 1995). Casarini (2006) observed that $R$. agassizi was the most abundant species in the depth range of $10-50 \mathrm{~m}$ in southeast Brazil.

Sexual segregation was not observed in this work and sex ratio favored the females. The same was observed by Casarini (2006) for the same species in the same area. However, unisexual aggregations of Raja clavata were recorded off the coast of East Anglia by Holden (1975), and could be common for rajids (Steven, 1933). For the southwestern Atlantic, Sympterygia acuta, S. bonapartii and Atlantoraja cyclophora do not segregate by sexes (De Queiroz, 1986; Oddone \& Vooren, 2004, 2005). Ebert (2005) studied eight Bathyraja species, recording no sexual segregation in six of them and a sex ratio favoring males in only two, along the eastern Bering Sea continental slope.

Data on the distribution of sizes in the catch can indicates a population's status or the risk of overfishing, as too 


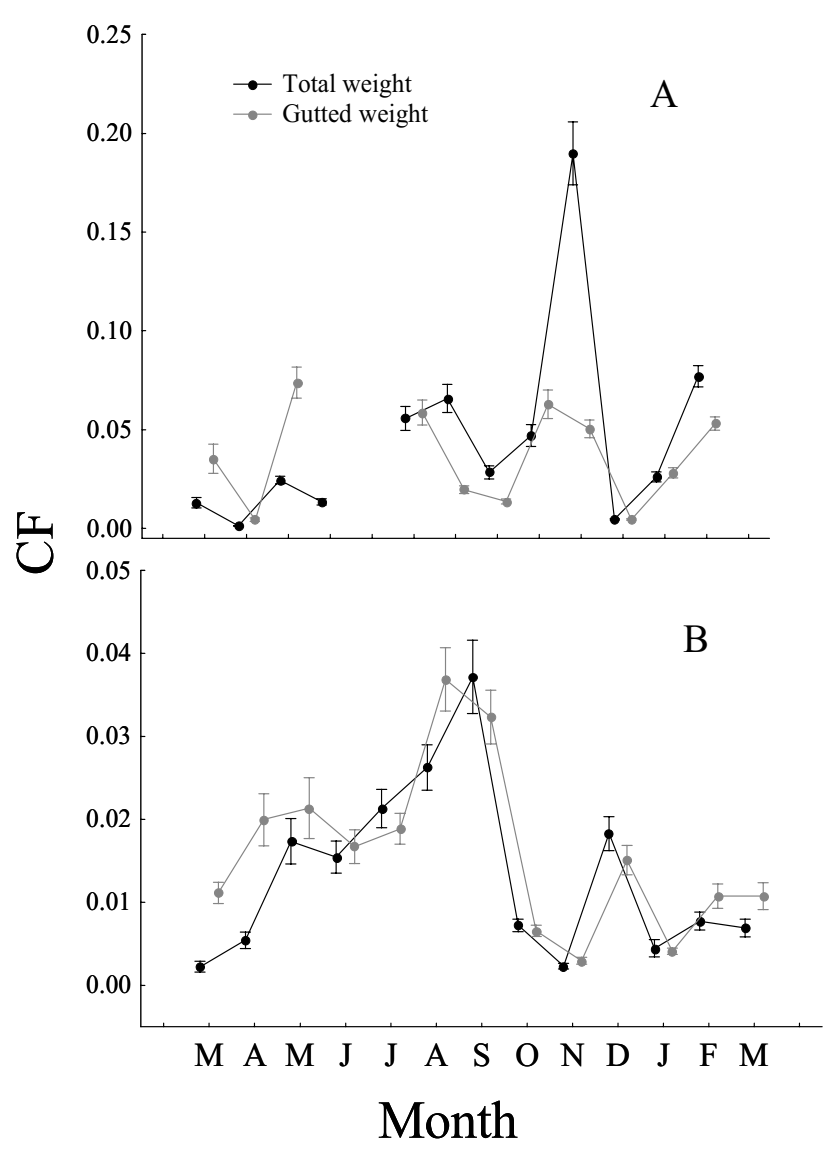

Fig. 6. Median condition factor by month (from March, 2005 to March, 2006) considering total (black line) and gutted weight (g) (grey line) for males (above) and females (below) of Rioraja agassizi. Vertical bars represent the data interval.

small fish may mean not enough are managing to spawn (Hilborn \& Walters, 1992). The same authors stated that young fish are less vulnerable to fishing gears than older ones. However, Oddone (unpublished data) recorded the presence of young and even neonates of $R$. agassizi and Atlantoraja spp., a fact that to date seemed to be unusual in rajids and that reflects the vulnerability of these life stages to bottom trawl fisheries. For the South Brazilian shelf Vooren \& Klippel (2005) did not record neonates of $R$. agassizi, at depths of 7$20 \mathrm{~m}$. Patterns of negative asymmetry in TL distributions, indicate that both for males and females, more specimens occurred with high values of TL and a few with low values of TL. A positive pattern of asymmetry would indicate just the opposite.

Negative asymmetric distribution of frequencies of TL for both sexes were observed in Atlantoraja cyclophora (Oddone $\&$ Vooren, 2004).

The largest specimen of $R$. agassizi recorded by Figueiredo (1977) was a $49 \mathrm{~cm}$ adult male. In this work the largest sizes observed were $59.4 \mathrm{~cm}$ for the females and $47.2 \mathrm{~cm}$ for the males, confirming the sexual dimorphism in size. In sharks, females attain maximum size and older age than males (Cortés, 2000). Several Rajidae are sexually dimorphic too, regarding size (Jardas, 1973; Nottage \& Perkins, 1983; Oddone \& Vooren, 2004). Exceptionally, Ebert (2005) observed that in Bathyraja interrupta, B. minispinosa and B. parmifera, males attained a larger size than females, while in $B$. lindbergi, B. maculata and $B$. trachura both sexes grew to approximately the same size, observing that only in B. aleutica and B. taranetzi did females achieve noticeably larger sizes than males. Cousseau et al. (2000) in Argentinean waters recorded contrasting maximum TLs of $61.8 \mathrm{~cm}$ for a male and $70.8 \mathrm{~cm}$ for a female of $R$. agassizi. This suggests a size gradient in the TL for $R$. agassizi, which increases southward, and which was already noted in teleost fishes (Wootton, 1996).

Sexually dimorphic length-weight relationships, were observed in A. cyclophora (total and gutted weight), Psammobatis normani, P. extenta and S. bonapartii (Braccini \& Chiaramonte, 2002; Mabragaña et al., 2002; Oddone \& Vooren, 2004; Mabragaña \& Cousseau, 2004), though Raja miraletus showed an opposite pattern (Ungaro, 2004). In this work, it was observed that throughout the year, males and females grew with negative allometry with TL, with exception of spring when females followed a pattern of positive allometry. This could be due more to food availability in spring in the area than to reproduction, as in this species vitellogenesis, ovulation and egg-laying occur throughout the year (Oddone et al., 2007). Possible effect of stomach contents on the weight of the skates were avoided by calculating $b$ with gutted weight, so differences in body weight may well reflect differences in body condition.

The correlation coefficient of the ratio TL-Gw was particularly lower in the males (0.767). This would indicate that, in spite of the fact that such correlation was significant for the potential curve adjusted, a trend in the Gw to increase more slowly with total length exists, when compared with Tw, for a given TL value. This fact was not evident in the females and could then be related to the sexual dimorphism in the body shape that is observed in rajid species, i.e., males present a striking concavity in the anterior part of the disc, from the snout to the tip of the pectoral fins, which is not observed in the females. When considering Tw, such trend is likewise masked by the effect of the viscera and especially stomach content, reflecting a more typical potential curve pattern because of the higher value of the angular coefficient $b$.

In summer, b was estimated to be 2.984 and 2.888 for total and gutted weight respectively. Although these values were statistically different from 3 , the sample number (71) may be considered, because the larger the sample size, the more the significance of the differences, and therefore for this season growth could have been isometric as well. Braccini \& Chiaramonte (2002) recorded isometric growth for males and positive allometric growth in females of $P$. extenta.

The condition factor can provide information on the general condition of fishes in the habitat they live, as well as indicate phenomena such as spawning period, alterations in population density and feeding conditions (Braga, 1986). In R. agassizi, CF varied significantly throughout the year, reflecting variations in the availability of food and mainly in the 
reproductive events, such as egg-laying, vitellogenesis and production of the egg cases. Seasonal variation of the diet seems to be associated with the availability of the prey, whose distribution and abundance are related to the dynamics of the water masses of the region (Muto et al., 2001). Loefer \& Sedberry (2003) observed that in Rhizoprionodon terraenovae the condition factor in both sexes was low during the mating season, an indication of probable stress.

The CF may also be influenced by the liver weight's variation throughout the year, as the liver is strongly correlated with reproduction in rajids (Oddone \& Velasco, 2006) and elasmobranchs in general. Sexual dimorphism in the liver weight was noted already in several rajid species, and this is related to the energy expenditure of females during vitellogenesis, oocyte maturation and gestation. Females store great quantities of lipids in the liver during the pre-vitellogenic phase of the reproductive cycle (Lucifora et al., 2002), and the production of vitellogenin (the precursor to egg yolk proteins), takes place in the liver (Gelsleichter, 2004). In Raja asterias, for instance, an increase in the gonad weight is accompanied by the storage of substances in the liver (Capapé, 1980). In males of this species, two well defined annual peaks in the gonadosomatic index exist, while in the females of $R$. agassizi and others such as A. cyclophora (Oddone \& Vooren, 2005), such peaks are not that evident, confirming the absence of seasonality in the reproductive variables, such as gonad weight, egg-laying frequency throughout the year, etc. This observation may well explain the rather greater variation for males in the $\mathrm{CF}$ (with regard to Gw), by the end of the year (December) when compared with females.

A growth pattern where males are wider than females in the first life stages, turning the females wider than males from a given $\mathrm{TL}$, may be typical of at least some rajids and was also observed in A. cyclophora (Oddone, 2003; Oddone \& Vooren, 2004).

\section{Acknowledgements}

Skippers Gonzalez Antônio do Nascimento \& Pedro Silva (Cigano do Mar II \& III); Airton Faria \& José dos Santos (Antares I \& Polares III); Antonio de Oliveira Neto (Franzese III); Oséias Vicente (São Paulo IV); Waldecir da Silva (São Paulo II); Edgar Nascimento dos Santos (Dourado \& Araguaia); Gonzalez Antonio do Nascimento (São Paulo VI \& XI) and Jorge da Silva (Jangadeiro XV). The first author has a FAPESP (São Paulo State Foundation for Research Support) Ph.D. grant.

\section{Literature Cited}

Barbosa dos Santos, F. \& U. L. Gomes. 1998. Morfologia juvenil de quatro espécies do gênero Raja (Linneaus, 1758) das regiões sudeste do Brasil (Chondrichthyes, Batoidei, Rajidae). Biociências, 6(2): 125-146.

Braccini, J. M. \& G. E. Chiaramonte 2002. Reproductive biology of Psammobatis extenta. Journal of Fish Biology, 61, 272-288.

Braga, F. M. S. 1986. Estudo entre fator de condição e relação peso/ comprimento para alguns peixes marinhos. Revista Brasileira de Biologia, 46(2): 339-346.
Brander, K. 1981. Disappearance of common skate Raia batis from Irish Sea. Nature, 290: 48-49.

Capapé, C. 1980. Contribution à la biologie des Rajidae des côtes tunisiennes. 21. Raja asterias, Delaroche, 1809: relations taillepoids, taille-poids du foie, taille-poids des gonades. Coefficients de condition. Rapports hépatosomatique et gonadosomatique. Bulletin de l'Office National des Pêches, 4:47-65.

Casarini, L. M. 1999. Distribuição, abundância, morfometria e aspectos da pesca das raias do gênero Raja (Elasmobranchii, Rajidae) da fauna acompanhante da pesca de arrasto na costa sudeste e sul do Brasil. São Paulo. Unpublished M.Sc. Dissertation, Universidade de São Paulo, São Paulo. 68 p.

Casarini, L. M. 2006. Dinâmica populacional de raias demersais do genero Atlantoraja e Rioraja (Elasmobranchii, Rajidae) da costa sudeste e sul do Brasil. Unpublished Ph.D. Dissertation, Universidade de São Paulo, São Paulo. 206 p.

Casey, J. M. \& R. A. Myers. 1998. Near extinction of a large, widely distributed fish. Science, 281: 690-691.

Compagno, L. J. V. 2005. Checklist of living Chondrichthyes. Pp 503-548. In: W. C. Hamlett (Ed), Reproductive biology and phylogeny of chondrichthyes, Sharks, batoids and chimaeras. Science Publishers, Inc. Enfield (NH), USA.

Cortés, E. 2000. Life-history patterns and correlations in sharks. Reviews in Fisheries Science, 8: 299-344.

Cousseau, M. B., D. E. Figueroa \& J. M. Díaz de Astarloa, 2000. Clave de identificación de las rayas del litoral marítimo de Argentina y Uruguay (Chondrichthyes, Familia Rajidae). Publicaciones especiales, Instituto Nacional de Investigación y Desarrollo Pesquero. Mar del Plata, 35p.

Dulvy, N. K. \& J. D. Reynolds. 2002. Predicting extinction vulnerability in skates. Conservation Biology, 16, 440-450.

Ebert, D. A. 2005. Reproductive biology of skates, Bathyraja (Ishiyama), along the eastern Bering Sea continental slope. Journal of Fish Biology, 66: 618-649.

Figueiredo, J. L. 1977. Manual de Peixes Marinhos do Sudeste do Brasil. Introdução: cações, raias e quimeras. Museu de Zoologia da Universidade de São Paulo, 104p.

Gelsleichter, J. 2004. Hormonal regulation of elasmobranch physiology. Pp. 287-323. In: J. C. Carrier, J. A. Musick \& R. Heithaus (Eds.), Biology of sharks and their relatives. CRC Press, Florida, 596p.

Hammer, O, D. A. T. Harper \& P. D. Ryan. 2001. PAST: Palaeontological Statistics software package for education and data analysis. Palaeontological Electronica, 4(1): 9 p. (Version 1.46, July 2006)

Hilborn, R. \& C. J. Walters. 1992. Quantitative fisheries stock assessment: choice, dynamics and uncertainty. Chapman \& Hall, London. 570 p.

Holden, M. J. 1975. The fecundity of Raja clavata in British waters. Journal du Conseil - Conseil International pour l'Exploration de la Mer, 36(2): 110-118.

Jardas, I. 1973. A contribution to our knowledge of the biology and ecology of thornback ray (Raja clavata L.) and brown ray (Raja miraletus L.) in the Adriatic. Acta Adriatica, 15: 1-42.

King, M. 1995. Fisheries biology, assessment and management. Fishing News Books. 341 p.

Last, P. R. \& G. K. Yearsley. 2002. Zoogeography and relationships of Australasian skates (Chondrichthyes: Rajidae). Journal of Biogeography, 29: 1627-1641

Loefer, J. K. \& G. R. Sedberry. 2003. Life history of the Atlantic sharpnose shark (Rhizoprionodon terraenovae)(Richardson, 1836) off the southeastern United States. Fishery Bulletin, 101: 75-88. 
Lucifora, L. O., R. Menni \& H. A. Escalante. 2002. Reproductive ecology and abundance of the sand tiger shark, Carcharias taurus, from the southwestern Atlantic. ICES Journal of Marine Science, 59:553-561.

Mabragaña, E. \& M. B. Cousseau. 2004. Reproductive biology of two sympatric skates in the south-west Atlantic: Psammobatis rudis and Psammobatis normani. Journal of Fish Biology, 65: 559-573.

Mabragaña, E., L. O. Lucifora \& A. M. Massa. M. 2002. The reproductive biology and abundance of Sympterygia bonapartii endemic to the south-west Atlantic. Journal of Fish Biology, 60: 951-967.

McEachran, J. D. \& T. Miyake. 1990. Zoogeography and bathymetry of skates (Chondrichthyes, Rajoidei). Pp. 305-326. In: Elasmobranchs as Living Resources: Advances in the Biology, Ecology, Systematics, and the Status of the Fisheries. H. L. Pratt Jr., S. H. Gruber \& T. Taniuchi (Eds.). NOAA Technical Report NMFS 90, U. S. Department of Commerce.

McEachran, J. D. \& N. Aschliman. 2004. Phylogeny of Batoidea. Pp. 79-113. In: Carrier, J. C., Musick, J. A. \& M. R. Heithaus (Eds.). Biology of sharks and their relatives. CRC Press, London, $596 \mathrm{p}$.

McEachran, J. D. \& G. Notarbartolo di Sciara. 1995. Peces Batoideos. p. 745-792. In: Fischer, W., F. Krupp, F. Schneider, C. Sommer, K. E. Carpenter, \& V. H. Niem (Eds.). Guia FAO para la identificacion de especies para los fines de la pesca. Pacifico centro-oriental. Vol. 2. Vertebrados. Parte 1. FAO, Rome.

Meneses, P. \& L. Paesch. 2003. Guía de campo para la identificación de peces cartilaginosos en el Río de la Plata y su frente oceánico. Frente Marítimo, 19, 137-185.

Menni, R. C. \& A. E. Gosztonyi, 1982. Benthic and semidemersal fish associations in the Argentine Sea. Studies on Neotropical Fauna \& Environment, 17: 1-29.

Menni, R. C. \& H. L. López. 1984. Distributional Patterns of Argentine Marine Fishes. Physis (Buenos Aires), A-42 (103): 71-85.

Menni, R. C., H. L. López \& M. L. García, 1981. Lista comentada de las especies de peces colectadas durante la campaña V del B/ I "Shinkai Maru" en el Mar Argentino. Contribuciones del Instituto Nacional de Investigaciones Pesqueras No 383: 267-280.

Muto, E. Y., L. S. H. Soares \& R. Goiten. 2001. Food resource utilization of the skates Rioraja agassizii (Müller \& Henle, 1841) and Psammobatis extenta (Garman, 1913) on the continental shelf off Ubatuba, South-eastern Brazil. Revista Brasileira de Biologia, 61 (2): 217-238.

Nottage, A. S. \& E. J. Perkins. 1983. Growth and maturation of rooker Raja clavata L. in the Solway Firth. Journal of Fish Biology, 23, 43-48.

Oddone, M. C. 2003. Biologia reprodutiva de Atlantoraja cyclophora (Regan, 1903) no Sul do Brasil. Rio Grande. Unpublished M.Sc. Dissertation. Fundação Universidade Federal do Rio Grande. $99 \mathrm{p}$.

Oddone, M. C., A. F. Amorim, P. L. Mancini, W. Norbis \& G. Velasco. 2007. The reproductive biology and cycle of Rioraja agassizi (Müller and Henle, 1841) (Chondrichthyes, Rajidae), in southeast Brazil, SW Atlantic Ocean. Scientia Marina, 71(3): 593-604.
Oddone, M. C. \& G. Velasco. 2006. Relationships between liver weight and body size throughout the year in Atlantoraja cyclophora (Elasmobranchii: Rajidae: Arhynchobatinae) and it's connection with reproduction. Neotropical Biology and Conservation. 1(1): 12-16

Oddone, M. C. \& C. M. Vooren. 2004. Distribution and abundance of Atlantoraja cyclophora (Regan 1903) (Elasmobranchii, Rajidae) with regard to salinity, temperature and depth in southern Brazil, south-western Atlantic. Neotropical Ichthyology, 2(3): 137-144.

Oddone, M. C. \& C. M. Vooren. 2005. Reproductive biology of Atlantoraja cyclophora (Regan 1903) (Elasmobranchii, Rajidae) off southern Brazil. ICES Journal of Marine Science, 62 (6): 1095-1103.

Paesch, L. 2006. Estructura de la comunidad de elasmobranquios en el Rio de la Plata y su frente oceanico. Unpublished M.Sc. Dissertation. Facultad de Ciencias, Universidad de la República. Montevideo. 122p.

Ponz Louro, M. 1995. Estratégias e tácticas reprodutivas de elasmobrânquios no ecossistema de Ubatuba, SP, Brasil. Unpublished M.Sc. Dissertation Universidade de São Paulo, São Paulo. 95p.

Queiroz, E. 1986. Estudo comparativo da alimentação de Sympterygia acuta Garman, 1887 e S. bonapartei Müller \& Henle, 1841 (Pisces: Rajiformes) com relação à distribuição, abundância, morfologia e reprodução, nas águas litorâneas do Rio Grande do Sul, Brasil. Umpublished M.Sc. Dissertation. Universidade Federal do Rio Grande, Rio Grande. 326p.

Simpfendorfer, C. A. \& M. R. Heupel. 2004. Assessing habitat use and movement. p. 553-572. In: Biology of sharks and their relatives. Carrier, J. C., J. A. Musick \& M. R Heithaus, (Eds.). New York. CRC Press.

Sokal, R. R. \& F. J. Rohlf. 1995. Biometry, 3rd. ed. W. H. Freeman, San Francisco. 887 p.

Souza, G. S. 1998. Introdução aos Modelos de Regressão Linear e Não-Linear. Brasília: Embrapa- SPI / Embrapa-SEA. 505 p.

Steven, G. A. 1933. Rays and Skates of Devon and Cornwall III. The proportions of the sexes in nature and in commercial landings, and their significance to the fishery. Journal of the Marine Biological Association of the United Kingdom, 18: 611625 .

Ungaro, N. 2004. Biological parameters of the brown ray, Raja miraletus, in the Southern Adriatic basin. Cybium, 28 (2): 174176.

Vooren, C. M. 1998. Demersal Elasmobranchs. p. 141-146. In: Seeliger, U., C. Odebrecht \& J. P. Castello (Eds). Os ecossistemas costeiro e marinho do extremo sul do Brasil. Ecoscientia, Rio Grande, 341 p.

Vooren, C. M. \& S. Klippel. 2005. Ações para a conservação de tubarões e raias no sul do Brasil. C. M. Vooren \& S. Klippel (Eds.). Porto Alegre. Igaré, $262 \mathrm{p}$.

Walker, P.A. 1999. Fleeting Images. Dynamics of North Sea Ray Populations. Unpublished Ph.D Thesis. Universiteit van Amsterdam. 142p.

Wootton, R. J. 1996. Fish Ecology, Blakie Academic \& Professional, $212 \mathrm{p}$. 